\title{
IMPACT OF SOME GROWTH STIMULANTS IN COOPERATION WITH ARBUSCULAR MYCORRHIZAL FUNGI ON GROWTH, PRODUCTIVITY AND CHEMICAL CONSTITUENTS OF DUTCH FENNEL PLANT
}

\author{
Y.F.Y. Mohamed \\ Horticulture Department, Faculty of Agriculture, Benha University, Egypt
}

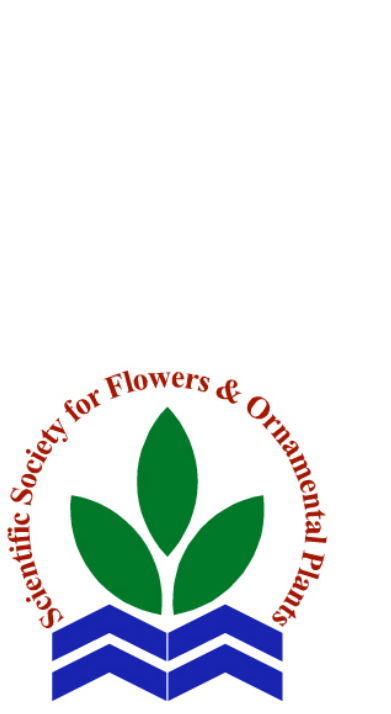

ABSTRACT: Fennel is an important medicinal, and aromatic plant
occupied the first in the list of Egyptian exports of herbs and spices.
Dutch fennel is described by a large percentage of anethole and a
lower percentage of estragole than the Egyptian fennel, therefore, it
is used as an antidote to some viral diseases. The present research
aims to investigate the influence of various growth stimulants
(amino acids, brassinolide, humic acid, salicylic acid, seaweeds
extract and tap water as control) and arbuscular mycorrhizal fungi as
well as their combinations on vegetative growth, productivity and
some chemical constituents of Dutch fennel plant (Foeniculum
vulgare Mill. spp. vulgare). This study was conducted at the
Experimental Farm and in the Laboratory at the Hort. Dept., Fac.
Agric. at Moshtohor, Benha Univ., Egypt, during 2018/2019 and
2019/2020 seasons. The greatest significant values of all studied
parameters were gained by the combined treatment of seaweed

Scientific J. Flowers \& extract at $2 \mathrm{ml} / \mathrm{l}$ with superior for the inoculum mycorrhizal fungi in Ornamental Plants, $\quad 1^{\text {st }}$ and $2^{\text {nd }}$ seasons. The largest seeds oil percentage (2.22 and 2.24) 7(3):303-319 (2020). was recorded by the combined treatment between seaweed extract

Received: combined with inoculum arbuscular mycorrhizal fungi (AMF). The

27/7/2020

Accepted: chemical constituents of Dutch fennel essential oil about ten components, the master components of essential oil constituents trans-anethole, estragole, and myrcene. In general, it could be $24 / 8 / 2020$ recommended that the combinations of seaweed extract at $2 \mathrm{ml} / \mathrm{l}$ and inoculum arbuscular mycorrhizal fungi (AMF) could be achieved the greatest growth, productivity and chemical constituents of Dutch fennel.

Key words: Dutch fennel, Foeniculum vulgare Mill. spp. vulgare, growth stimulants, mycorrhiza, seed yield, oil productivity.

\section{INTRODUCTION}

Fennel is an important medicinal and aromatic plant occupied the first in the list of Egyptian exports of herbs and spices. Family Apiaceae includes fennel, Foeniculum vulgare Miller, an herbaceous plant (Farrell, 1990; Wichtl and Bisset, 1994). Its origin is the Mediterranean and planted in many parts of the world i.e. Africa, Asia, Europe and some parts of South America (Blumenthal et al., 2000). Assiut and Qena Governorates,
Egypt represent the largest area of fennel around 11000 feddans (Abd El-Aleem et al., 2017). The fennel seeds and oils are used as an antidote to some viral diseases i.e. cancer, liver pain, colic in children and abdominal pains (Badgujar et al., 2014; Rather et al., 2012; Choi and Hwang, 2004; Koppula and Kumar, 2013). Dutch fennel (Foeniculum vulgare Mill. spp. vulgare) is a new strain of sweet fennel and imported from the Netherlands, as characterized by maximum 


\section{Y.F.Y. Mohamed}

seeds and oil yields, a higher percentage of anethole and a lower percentage of estragole in comparison of the Egyptian fennel (Shalaby et al., 2011).

In this context, major effort is applied as foliar spray of bio, organic fertilizers, natural biostimulators plus antioxidants. Here, amino acids more affect the activity of many enzymes, gene expression, and have a great vital role in plants. Brassinosteroids are among the safety biostimulators, they occur in free form and conjugated to sugars and fatty acids and are considered as highly promising, therefore, are considered one of the eco. safety growth stimulants. Humic acid (HA) has a large necessary for the plant and the soil as it works to enhance the properties of the soil and increase the rate of microbial activity as enhances the absorption of many nutrients in the soil. Salicylic acid (SA) antioxidant enzyme decreases generation of reactive oxygen species (ROS) and a signaling or messenger molecule in plants and induces plant tolerance against many biotic and abiotic stresses, so enhance plant tolerance to abiotic stress. Seaweeds comprise major and minor nutrients, amino acids, vitamins, cytokinins, auxin and abscisic acid such as growth promoting substances. Seaweeds reflexed the activity of enzymes, and consequently, and enhancement in biological processes in the plant. Finally, arbuscular mycorrhizal fungi (AMF) bio fertilizers, increase plant yield, enhance the plant uptake of immobile phosphate ions from the soil as well as $\mathrm{N}, \mathrm{P}$, $\mathrm{K}$, Mg etc... (Rai, 2002; Taiz and Zeiger, 2002; Kang and Guo, 2011; Bera et al., 2014; Berlyn and Russo, 1990; Horvath et al., 2007; Metwally et al., 2003; Crouch and Van Staden, 1994; EL-Boukhari et al., 2020; Smith et al., 2011 and Veresoglou et al., 2011).

The effect of some safety growth stimulant treatments and arbuscular mycorrhizal fungi on vegetative growth, yield and oil productivity in several studied of medicinal and aromatic plants was revealed by Mohamed et al. (2015) on
Ocimum basilicum, L. cv. Genovese plant, El-Khateeb (2017) on Majorana hortensis, Ibrahim and Helaly (2017) on fertilized fenugreek, Mahdy et al. (2019) on roselle, Mansori et al. (2019) on Salvia officinalis, Moghith (2019) on chia, Ghatas (2020) on Coriandrum sativum L. and also Mady (2020) on Dutch fennel.

The aim of this work was to appraise the benefits of supplementing some growth stimulating substances i.e. amino acids, brassinosteroids, humic acid, salicylic acid and seaweeds extract in the presence of arbuscular mycorrhizal fungi on vegetative growth, seed yield, oil production and the chemical constituents of Dutch fennel (Foeniculum vulgare Mill. spp. vulgare) plant.

\section{MATERIALS AND METHODS}

This study was executed successfully at the Experimental Farm and in the Laboratories of Horticulture Departments, Faculty of Agriculture at Moshtohor, Benha Univ., during 2018/2019 and 2019/2020 seasons to study the effect of some growth stimulant treatments i.e. amino acids, brassinolide, humic acid, salicylic acid and seaweeds extract and arbuscular mycorrhizal fungi as well as their combinations on vegetative growth, essential oil productivity and some chemical constituents of Dutch fennel (Foeniculum vulgare Mill. spp. vulgare) plant.

Dutch fennel seeds were obtained from Floriculture Farm, Horticulture Department, Faculty of Agriculture, Benha Univ. Seeds of Dutch fennel (1000 seed weight $12.77 \mathrm{~g}$ ) were sown in clayey loam soil on midOctober in both seasons in plots $(1 \times 1 \mathrm{~m})$ containing two rows (50 cm in between) every row has two hills (50 cm apart) and six weeks later, the plants were thinned, leaving only two seedling/hill.

Physical and chemical analysis of the experimental soil were determined according to Jackson (1973) and Black et al. (1982), respectively. The obtained results of soil analysis are presented in Table (1). 
Table 1. Mechanical and chemical analysis of the experimental soil.

\begin{tabular}{lcclcc}
\hline & \multicolumn{2}{c}{ Mechanical properties } & \multicolumn{3}{c}{ Chemical analysis } \\
Parameters & $\mathbf{2 0 1 8 / 2 0 1 9}$ & $\mathbf{2 0 1 9} / \mathbf{2 0 2 0}$ & Parameters & \multicolumn{2}{c}{ Values } \\
& $3.96 \%$ & $4.08 \%$ & Organic matter & $1.82 \%$ & $1.94 \%$ \\
\hline Coarse sand & $16.33 \%$ & $15.88 \%$ & CaCO $\%$ & $0.78 \%$ & $0.84 \%$ \\
Fine sand & $25.01 \%$ & $26.42 \%$ & Available nitrogen & $0.87 \%$ & $0.95 \%$ \\
Silt & $54.70 \%$ & $53.62 \%$ & Available phosphorus & $0.49 \%$ & $0.53 \%$ \\
Clay & Clayey loam & Clayey loam & Available potassium & $0.71 \%$ & $0.68 \%$ \\
Textural class & & & pH & 7.66 & 7.52 \\
& & & EC (dS/m) & 0.69 & 0.77 \\
\hline
\end{tabular}

The layout of the experiment was a complete randomized block design with two factors in three replicates. The first factor involving six growth stimulants treatments, whereas the second factor was devoted to two mycorrhizal fungi treatment (uninoculum and inoculum). Therefore, the experiment included 12 treatments with three replicates, each replicate contained 20 plants i.e. 60 plants in each treatment.

\section{Safety growth stimulants treatments:}

1. The control treatment (spray with tap water).

2. Amino acids as amino power at $2 \mathrm{ml} / \mathrm{l}$ for each as foliar spray, is a commercial product from Union for Agriculture Development (UAD) contain 20\% free Lamino acids, $40 \%$ total amino acids, 3\% mix of vitamins, $3.5 \%$ potassium citrate and some micro nutrients such as 1500 ppm Fe, 500 ppm Zn and 500 ppm Mn.

3. Brassinolide at $50 \mathrm{mg} / \mathrm{l}$ for each as foliar spray, was obtained from the Union for Agriculture Development Co. (UAD) Egypt.

4. Humic acid at $5 \mathrm{ml} / \mathrm{l}$ for each as a foliar spray, $80 \%$ soluble potassium humate. It is a commercial product by Leili Agrochemistry Co. Ltd. It includes: humic acid (80\%), $\mathrm{K}_{2} \mathrm{O}(11-13 \%)$ and Moisture (5-7\%).

5. Salicylic acid: salicylic acid solution sprayed at 200 ppm for each as foliar spray.

6. Seaweeds extract at $2 \mathrm{ml} / \mathrm{l}$ for each as foliar spray, seaweeds extract produced by Orbital for Agrochemicals, Egypt. The used extract contains minerals as $\mathrm{Fe}, \mathrm{Zn}$, $\mathrm{Cu}, \mathrm{Mn}$ and $\mathrm{Mo}$, vitamins, enzymes, amino acids, sugars, and plant hormones, (i.e. auxins, cytokinins and gibberellins).

The growth stimulants amino acids, brassinolide, humic acid, salicylic acid and seaweed extracts were applied as a foliar spray on plant leaves 4 times, the first one was added after 30 days from transplanting. The second time was after 15 days from the first, while the third was applied after 15 days from the second and the fourth was after 15 days from the third. Spraying was done to the run off the plant foliage,

Using bio-film at $1 \mathrm{ml} / \mathrm{l}$ as a wetting agent, was added to all tested solutions including the control. Treated plants were sprayed with a hand pump mister till run off, whereas control plants were sprayed with tap water. Common agricultural practices (irrigation, fertilization, manual weed control, ... etc.) were carried out when needed.

\section{Arbuscular mycorrhizal fungi:}

Arbuscular mycorrhizal fungi inoculum consisted of roots, hyphae, spores and growth media from a pot culture of onion plants colonization with Glomus mosseae NRC31 and Glomus fasciculatum NRC15 originally isolated from Egyptian soils and multiplied on sterilized peat:vermicolite: perlit (Badr El-Din et al., 1999). Arbuscular mycorrhizal fungi were obtained from Agricultural Microbiology Department, National Research Center. Inoculum material contained 275 spores $\mathrm{g}^{-1}$ oven dry bases in addition to the colonization roots pieces (the infectivity 104 propagola). Mycorrhizal 
fungi inoculation was done by mixing $20 \mathrm{~g}$ of it with $5 \mathrm{~g}$ of fennel seed before cultivation and then after 10 days by injection into the soil in roots area of seedlings from four sides at $3.5 \mathrm{~g} / \mathrm{hill}$ of inoculum material.

\section{Harvesting:}

The plants were harvested on May, $1^{\text {st }}$ in the first and second seasons.

\section{Data measurements and recorded:}

The vegetative and yield parameters were measured and recorded at harvesting time on May, $1^{\text {st }} 2019$ and 2020 as follows: the vegetative parts were cut about $1 \mathrm{~cm}$ above the soil surface. Measurements of the following traits were collected:

1. Vegetative characteristics at the beginning of flowering: height of plant $(\mathrm{cm})$, branches No./plant and fresh and dry weights of the plant (g/plant).

2. Seeds yield parameters: after harvesting time plants were removed to station for sampling and other measurements, the following measurements were taken; umbels No./plant, 1000 seeds weight (g), weight of seeds/plant (g) and weight of seeds/feddan (ton).

3. Essential oil parameters:

a. Essential oil percentage was calculated as $\mathrm{ml}$ of oil/100 grams of seeds using the following equation:

Essential oil percentage $=$ oil volume in the graduated tube/dry weight of samples $\times 100$

b. Essential oil yield/plant (ml).

c. Essential oil yield/feddan (l).

Essential oil percentage of fennel fruits was determined by hydro distillation for $3 \mathrm{~h}$ using the method of Guenther (1961), the oil percentage was used to calculate essential oil yield/plant (ml), and feddan (l). The extracted volatile oil was dehydrated over anhydrous sodium sulphate and stored in a refrigerator until GC/MS analysis.
4. Chemical constituents:

a. Photosynthetic pigments: chlorophyll a, b and carotenoids were colorimetrically determined in leaves of fennel according to the method described by Inskeep and Bloom (1985) and calculated as mg/g fresh weight.

b. Nitrogen, phosphorus, potassium and total carbohydrates \% were determined in dried fennel leaves according to the methods described by Horneck and Miller (1998), Hucker and Catroux (1980), Horneck and Hanson (1998) and Chaplin and Kennedy (1994), respectively.

\section{GLC analysis of essential oil:}

The GLC analysis for oil samples from the second season only from the first experiment was carried out at the Medicinal and Aromatic Plant Laboratory, Dokki, Egypt. The gas liquid chromatography was analyzed according to Guenther (1961) and British Pharm. (1980).

\section{Statistical analysis:}

The design of the experiment was factorial experiment in a complete randomized block design, the differences between the mean values of various treatments were compared by Duncan's multiple range test (Duncan's, 1955) as given by Snedecor and Cochran (1989) using MSTAT-C statistical software package.

\section{RESULTS AND DISCUSSION}

Effect of some growth stimulant treatments, arbuscular mycorrhizal fungi and their combination treatments on:

\section{Vegetative growth measurements:}

Concerning the effect of foliar spray of some growth stimulants treatments, data presented in Tables (2 and 3) declared that, the foliar spray of each of amino acid (amino power) at $2 \mathrm{ml} / \mathrm{l}$, brassinolide at $50 \mathrm{mg} / \mathrm{l}$, humic acid at $5.0 \mathrm{ml} / \mathrm{l}$, salicylic acid (SA) at $200 \mathrm{ppm}$ and seaweed extract at $2 \mathrm{ml} / \mathrm{l}$ 
Table 2. Effect of some growth stimulants, mycorrhizal fungi and their combination treatments on plant height and number of branches/plant of Dutch fennel (Foeniculum vulgare Mill.), during 2018/2019 and 2019/2020 seasons.

\begin{tabular}{|c|c|c|c|c|c|c|}
\hline \multirow{3}{*}{ Growth stimulants } & \multicolumn{3}{|c|}{ Height of plant (cm) } & \multicolumn{3}{|c|}{ Branches No./plant } \\
\hline & \multicolumn{6}{|c|}{ First season } \\
\hline & $\begin{array}{c}\text { Uninoculum } \\
\text { AMF }\end{array}$ & $\begin{array}{c}\text { Inoculum } \\
\text { AMF }\end{array}$ & Mean (A) & $\begin{array}{c}\text { Uninoculum } \\
\text { AMF }\end{array}$ & $\begin{array}{l}\text { Inoculum } \\
\text { AMF }\end{array}$ & Mean (A) \\
\hline Control (tap water) & 59.391 & $63.40 \mathrm{k}$ & $61.40 \mathrm{f}$ & $12.33 \mathrm{f}$ & $15.67 \mathrm{e}$ & $14.00 \mathrm{e}$ \\
\hline Amino power at $2 \mathrm{ml} / \mathbf{l}$ & $90.00 \mathrm{f}$ & $93.47 \mathrm{~d}$ & $91.74 \mathrm{c}$ & $19.33 \mathrm{~d}$ & $21.33 \mathrm{c}$ & $20.33 \mathrm{c}$ \\
\hline Brassinolide at $50 \mathrm{mg} / \mathrm{l}$ & $71.37 \mathrm{i}$ & $75.32 \mathrm{~g}$ & $73.34 \mathrm{~d}$ & $16.33 \mathrm{e}$ & $18.33 \mathrm{~d}$ & 17.33 c \\
\hline Humic acid at $5.0 \mathrm{ml} / \mathrm{l}$ & $92.03 \mathrm{e}$ & 96.09 c & $94.06 \mathrm{~b}$ & $19.33 \mathrm{~d}$ & $23.33 \mathrm{~b}$ & $21.33 \mathrm{~b}$ \\
\hline SA at 200 ppm & $67.39 \mathrm{j}$ & $73.32 \mathrm{~h}$ & 70.35 e & $15.33 \mathrm{e}$ & $18.00 \mathrm{~d}$ & $16.67 \mathrm{~d}$ \\
\hline Seaweeds extract at $2 \mathrm{ml} / \mathrm{l}$ & $99.53 \mathrm{~b}$ & 106.3 a & 102.9 a & $23.33 \mathrm{~b}$ & $26.00 \mathrm{a}$ & $24.67 \mathrm{a}$ \\
\hline \multirow[t]{2}{*}{ Mean (B) } & $79.95 \mathrm{~b}$ & 84.65 a & & $17.67 \mathrm{~b}$ & $20.44 \mathrm{a}$ & \\
\hline & \multicolumn{6}{|c|}{ Second season } \\
\hline Control (tap water) & $59.50 \mathrm{~h}$ & $66.31 \mathrm{~g}$ & $62.90 \mathrm{f}$ & $12.67 \mathrm{f}$ & $16.33 \mathrm{e}$ & $14.50 \mathrm{~d}$ \\
\hline Amino power at $2 \mathrm{ml} / \mathbf{l}$ & $90.74 \mathrm{~d}$ & $95.04 \mathrm{c}$ & 92.89 c & 20.33 c & $22.33 \mathrm{~b}$ & $21.33 \mathrm{~b}$ \\
\hline Brassinolide at $50 \mathrm{mg} / \mathrm{l}$ & $70.71 \mathrm{f}$ & $75.34 \mathrm{e}$ & $73.03 \mathrm{~d}$ & $15.67 \mathrm{e}$ & $19.33 \mathrm{~cd}$ & $17.50 \mathrm{c}$ \\
\hline Humic acid at $5.0 \mathrm{ml} / \mathrm{l}$ & $94.03 \mathrm{c}$ & $97.81 \mathrm{~b}$ & $95.92 \mathrm{~b}$ & $19.33 \mathrm{~cd}$ & $23.00 \mathrm{~b}$ & $21.17 \mathrm{~b}$ \\
\hline SA at 200 ppm & $69.48 \mathrm{f}$ & $74.03 \mathrm{e}$ & $71.76 \mathrm{e}$ & $16.33 \mathrm{e}$ & $18.33 \mathrm{~d}$ & $17.33 \mathrm{c}$ \\
\hline Seaweeds extract at $2 \mathrm{ml} / \mathrm{l}$ & $97.00 \mathrm{~b}$ & $107.4 \mathrm{a}$ & $102.2 \mathrm{a}$ & $22.33 \mathrm{~b}$ & 26.67 a & $24.50 \mathrm{a}$ \\
\hline Mean (B) & $80.24 \mathrm{~b}$ & 86.00 a & & $17.78 \mathrm{~b}$ & $21.00 \mathrm{a}$ & \\
\hline
\end{tabular}

AMF = Arbuscular mycorrhizal fungi; SA= Salicylic acid

Table 3. Effect of some growth stimulants, mycorrhizal fungi and their combination treatments on herb fresh and dry weights (g/plant) of Dutch fennel (Foeniculum vulgare Mill.), during 2018/2019 and 2019/2020 seasons.

\begin{tabular}{|c|c|c|c|c|c|c|}
\hline \multirow{3}{*}{ Growth stimulants } & \multicolumn{3}{|c|}{ Herb fresh weight (g/plant) } & \multicolumn{3}{|c|}{ Herb dry weight (g/plant) } \\
\hline & \multirow[b]{2}{*}{$\begin{array}{c}\text { Uninoculum } \\
\text { AMF }\end{array}$} & \multicolumn{3}{|c|}{ First season } & \multirow[b]{2}{*}{$\begin{array}{l}\text { Inoculum } \\
\text { AMF }\end{array}$} & \multirow[b]{2}{*}{ Mean (A) } \\
\hline & & $\begin{array}{l}\text { Inoculum } \\
\text { AMF }\end{array}$ & Mean (A) & $\begin{array}{c}\text { Uninoculum } \\
\text { AMF }\end{array}$ & & \\
\hline Control (tap water) & $168.1 \mathrm{k}$ & $171.9 \mathrm{j}$ & $170.0 \mathrm{f}$ & 54.621 & $61.03 \mathrm{k}$ & $57.83 \mathrm{f}$ \\
\hline Amino power at 2ml/l & $457.3 \mathrm{e}$ & $462.3 \mathrm{~d}$ & 459.8 c & $165.8 \mathrm{f}$ & $168.4 \mathrm{e}$ & 167.1 c \\
\hline Brassinolide at 50 mg/l & $410.5 \mathrm{~g}$ & $417.0 \mathrm{f}$ & $413.8 \mathrm{~d}$ & $151.4 \mathrm{~h}$ & $153.9 \mathrm{~g}$ & $152.6 \mathrm{~d}$ \\
\hline Humic acid at $5.0 \mathrm{ml} / \mathbf{l}$ & $462.3 \mathrm{~d}$ & 469.2 c & $465.8 \mathrm{~b}$ & $171.0 \mathrm{~d}$ & $174.6 \mathrm{c}$ & $172.8 \mathrm{~b}$ \\
\hline SA at $200 \mathrm{ppm}$ & $359.8 \mathrm{i}$ & $369.0 \mathrm{~h}$ & $364.4 \mathrm{e}$ & $135.9 \mathrm{j}$ & $140.3 \mathrm{i}$ & $138.1 \mathrm{e}$ \\
\hline Seaweeds extract at $2 \mathrm{ml} / \mathrm{l}$ & $479.4 \mathrm{~b}$ & 487.4 a & 483.4 a & $177.9 \mathrm{~b}$ & 181.3 a & 179.6 a \\
\hline \multirow[t]{2}{*}{ Mean (B) } & $389.6 \mathrm{~b}$ & $396.1 \mathrm{a}$ & & $142.8 \mathrm{~b}$ & 146.6 a & \\
\hline & \multicolumn{6}{|c|}{ Second season } \\
\hline Control (tap water) & $170.3 \mathrm{k}$ & $172.7 \mathrm{j}$ & $171.5 \mathrm{f}$ & 56.561 & $61.33 \mathrm{k}$ & $58.95 \mathrm{f}$ \\
\hline Amino power at 2ml/l & $459.3 \mathrm{e}$ & $464.4 \mathrm{~d}$ & 461.9 c & $165.7 \mathrm{f}$ & $171.0 \mathrm{e}$ & $168.4 \mathrm{c}$ \\
\hline Brassinolide at 50 mg/l & $412.5 \mathrm{~g}$ & $417.1 \mathrm{f}$ & $414.8 \mathrm{~d}$ & $151.7 \mathrm{~h}$ & $154.9 \mathrm{~g}$ & $153.3 \mathrm{~d}$ \\
\hline Humic acid at $5.0 \mathrm{ml} / \mathrm{l}$ & $466.1 \mathrm{~d}$ & $473.0 \mathrm{c}$ & $469.6 \mathrm{~b}$ & $172.4 \mathrm{~d}$ & $175.4 \mathrm{c}$ & $173.9 \mathrm{~b}$ \\
\hline SA at $200 \mathrm{ppm}$ & $362.5 \mathrm{i}$ & $372.7 \mathrm{~h}$ & $367.6 \mathrm{e}$ & $136.7 \mathrm{j}$ & $141.9 \mathrm{i}$ & 139.3 e \\
\hline Seaweeds extract at $2 \mathrm{ml} / \mathrm{l}$ & $481.3 \mathrm{~b}$ & 490.0 a & 485.6 a & $180.0 \mathrm{~b}$ & 181.7 a & $180.8 \mathrm{a}$ \\
\hline Mean (B) & $392.0 \mathrm{~b}$ & 398.3 a & & $143.8 \mathrm{~b}$ & 147.7 a & \\
\hline
\end{tabular}

AMF = Arbuscular mycorrhizal fungi; SA= Salicylic acid 


\section{Y.F.Y. Mohamed}

during the two growing seasons increased all measured vegetative growth parameters of Dutch fennel (Foeniculum vulgare Mill.) expressed as plant height, number of branches, herb fresh and dry weights/plant (g) compared with the control (tap water) treatment. In this connection, seaweed extract at $2 \mathrm{ml} / \mathrm{l}$ reflected the highest values of all studied vegetative growth traits followed by humic acid and amino acids in descending order.

On the other side, all vegetative growth mentioned above were increased by using arbuscular mycorrhizal fungi (AMF) when compared to untreated (uninoculum mycorrhizal fungi).

As for the interaction between some growth stimulants treatments and mycorrhizal fungi treatments, the same data in Tables (2 and 3) reveal that the highest values in all measured growth traits were recorded as a result of using seaweed extract combined with arbuscular mycorrhizal fungi (AMF) (uninoculum and inoculum) with superior for the inoculum mycorrhizal fungi. In this context, the second values of these parameters were recorded by using the combined treatment between humic acid at 5 $\mathrm{ml} / \mathrm{l}$ and inoculum mycorrhizal, followed descendingly by the combined treatment between amino acid (amino power) at $2 \mathrm{ml} / \mathrm{l}$ and mycorrhizal fungi in $1^{\text {st }}$ an $2^{\text {nd }}$ seasons.

\section{Seeds yield parameters:}

Data presented in Tables (4 and 5) illustrated that, all the four used growth stimulants treatments progressively increased the seeds yield parameters i.e. number of umbels/plant, weight of 1000 seed (g), seeds yield/plant (g) and seeds yield/feddan (ton) of Dutch fennel (Foeniculum vulgare Mill.) as compared with control in both seasons. Hence, in the two consecutive seasons of this study the highest values of these parameters were obtained from the seaweed extract at $2 \mathrm{ml} / \mathrm{l}$, followed by humic acid at $5.0 \mathrm{ml} / \mathrm{l}$ which scored the second highest values with the exception of number of umbels/plant.
Whereas the second highest values of number of umbels/plants was resulted by amino acid (amino power) at $2 \mathrm{ml} / \mathrm{l}$. Irrespective of control, the lowest values of aforementioned parameters were scored by salicylic acid (SA) at $200 \mathrm{ppm}$ and brassinolide at $50 \mathrm{mg} / \mathrm{l}$, in ascending order. On the other hand, inoculated the Dutch fennel plant with mycorrhizal fungi significantly increased these parameters when compared to the untreated (uninoculum mycorrhizal fungi). Additionally, data presented in Tables (4 and 5) recorded that all the interactions between growth stimulants and arbuscular mycorrhizal fungi (AMF) treatments statistically improved the aforementioned seed parameters, Dutch fennel plant when compared to control in both seasons especially, the combination between seaweed extract combined and inoculum arbuscular mycorrhizal fungi (AMF) significantly produced the highest values of these parameters in the first and second seasons. Also, seaweed extract combined with uninoculum arbuscular mycorrhizal fungi (AMF) or the combined treatment between amino acid at $2 \mathrm{ml} / \mathrm{l}$ and inoculum mycorrhizal fungi recorded highly increments of these parameters in both seasons. The minimum values of abovementioned parameters were obtained by control plants (tap water) or salicylic acid (SA) at 200 ppm especially uninoculum mycorrhizal fungi, in an ascending order and in the both seasons.

The obtained results of some safety growth stimulants treatments and arbuscular mycorrhizal fungi on vegetative growth, yield and in several studied parameters of medicinal and aromatic plants was revealed by Mohamed et al. (2016) on basil plant, ElKhateeb (2017) of Majorana hortensis, Ibrahim and Helaly (2017) on fenugreek plants. Mansori et al. (2019) demonstrated that, the application of seaweeds extracts enhances the vegetative growth of Salvia officinalis plant. Moghith (2019) declared that, plants inoculum of mycorrhizal fungi scores the highest significant increases of all 
Table 4. Effect of some growth stimulants, mycorrhizal fungi and their combination treatments on number of umbels/plant and weight of 1000 seeds (g) of Dutch fennel (Foeniculum vulgare Mill.), during 2018/2019 and 2019/2020 seasons.

\begin{tabular}{|c|c|c|c|c|c|c|}
\hline \multirow{3}{*}{ Growth stimulants } & \multicolumn{3}{|c|}{ Umbels No. /plant } & \multicolumn{3}{|c|}{1000 seeds weights (g) } \\
\hline & \multicolumn{6}{|c|}{ First season } \\
\hline & $\begin{array}{c}\text { Uninoculum } \\
\text { AMF }\end{array}$ & $\begin{array}{l}\text { Inoculum } \\
\text { AMF }\end{array}$ & Mean (A) & $\begin{array}{c}\text { Uninoculum } \\
\text { AMF }\end{array}$ & $\begin{array}{l}\text { Inoculum } \\
\text { AMF }\end{array}$ & Mean (A) \\
\hline Control (tap water) & $58.33 \mathrm{k}$ & $67.67 \mathrm{j}$ & $63.00 \mathrm{f}$ & $11.89 \mathrm{~g}$ & $12.38 \mathrm{f}$ & $12.13 \mathrm{e}$ \\
\hline Amino power at 2ml/l & $80.00 \mathrm{e}$ & $86.67 \mathrm{c}$ & $83.33 \mathrm{c}$ & $14.72 \mathrm{c}$ & $15.11 \mathrm{~b}$ & $14.91 \mathrm{~b}$ \\
\hline Brassinolide at $50 \mathrm{mg} / \mathrm{l}$ & $71.00 \mathrm{~h}$ & $76.67 \mathrm{f}$ & $73.83 \mathrm{~d}$ & $13.34 \mathrm{e}$ & $13.89 \mathrm{~d}$ & $13.61 \mathrm{~d}$ \\
\hline Humic acid at $5.0 \mathrm{ml} / \mathrm{l}$ & $82.67 \mathrm{~d}$ & $86.33 \mathrm{c}$ & $84.50 \mathrm{~b}$ & $14.10 \mathrm{~d}$ & $14.99 \mathrm{bc}$ & $14.55 \mathrm{c}$ \\
\hline SA at 200 ppm & $69.33 \mathrm{i}$ & $74.00 \mathrm{~g}$ & $71.67 \mathrm{e}$ & $13.10 \mathrm{e}$ & $13.79 \mathrm{~d}$ & $13.44 \mathrm{~d}$ \\
\hline Seaweeds extract at $2 \mathrm{ml} / \mathrm{l}$ & $92.00 \mathrm{~b}$ & $97.33 \mathrm{a}$ & $94.67 \mathrm{a}$ & $14.90 \mathrm{bc}$ & 15.55 a & $15.23 \mathrm{a}$ \\
\hline \multirow[t]{2}{*}{ Mean (B) } & $75.56 \mathrm{~b}$ & $81.44 \mathrm{a}$ & & $13.68 \mathrm{~b}$ & $14.28 \mathrm{a}$ & \\
\hline & \multicolumn{6}{|c|}{ Second season } \\
\hline Control (tap water) & $60.00 \mathrm{~h}$ & $69.00 \mathrm{~g}$ & $64.50 \mathrm{e}$ & $11.99 \mathrm{e}$ & $12.26 \mathrm{e}$ & $12.12 \mathrm{~d}$ \\
\hline Amino power at $2 \mathrm{ml} / \mathbf{l}$ & $81.67 \mathrm{~d}$ & $87.00 \mathrm{c}$ & $84.33 \mathrm{c}$ & $14.96 \mathrm{a}$ & $14.84 \mathrm{a}$ & $14.90 \mathrm{a}$ \\
\hline Brassinolide at $50 \mathrm{mg} / \mathrm{l}$ & $70.33 \mathrm{~g}$ & $77.00 \mathrm{e}$ & $73.67 \mathrm{~d}$ & $13.37 \mathrm{~cd}$ & $13.90 \mathrm{bc}$ & $13.63 \mathrm{c}$ \\
\hline Humic acid at $5.0 \mathrm{ml} / \mathrm{l}$ & $83.67 \mathrm{~d}$ & $89.00 \mathrm{c}$ & $86.33 \mathrm{~b}$ & $14.11 \mathrm{~b}$ & $14.89 \mathrm{a}$ & $14.50 \mathrm{~b}$ \\
\hline SA at 200 ppm & $70.33 \mathrm{~g}$ & $74.00 \mathrm{f}$ & $72.17 \mathrm{~d}$ & $13.17 \mathrm{~d}$ & $13.74 \mathrm{~b}-\mathrm{d}$ & $13.46 \mathrm{c}$ \\
\hline Seaweeds extract at $2 \mathrm{ml} / \mathrm{l}$ & $93.33 \mathrm{~b}$ & 98.33 a & 95.83 a & $15.11 \mathrm{a}$ & $15.44 \mathrm{a}$ & $15.27 \mathrm{a}$ \\
\hline Mean (B) & $76.56 \mathrm{~b}$ & 82.39 a & & $13.78 \mathrm{~b}$ & $14.18 \mathrm{a}$ & \\
\hline
\end{tabular}

AMF = Arbuscular mycorrhizal fungi; SA= Salicylic acid

Table 5. Effect of some growth stimulants, mycorrhizal fungi and their combination treatments on seeds yield/plant (g) and seeds yield/feddan (ton) of Dutch fennel (Foeniculum vulgare Mill.), during 2018/2019 and 2019/2020 seasons.

\begin{tabular}{|c|c|c|c|c|c|c|}
\hline \multirow{3}{*}{ Growth stimulants } & \multicolumn{3}{|c|}{ Seeds yield/plant (g) } & \multicolumn{3}{|c|}{ Seeds yield/feddan (ton) } \\
\hline & \multicolumn{6}{|c|}{ First season } \\
\hline & $\begin{array}{c}\text { Uninoculum } \\
\text { AMF }\end{array}$ & $\begin{array}{l}\text { Inoculum } \\
\text { AMF }\end{array}$ & Mean (A) & $\begin{array}{c}\text { Uninoculum } \\
\text { AMF }\end{array}$ & $\begin{array}{l}\text { Inoculum } \\
\text { AMF }\end{array}$ & Mean (A) \\
\hline Control (tap water) & $30.29 \mathrm{k}$ & $35.29 \mathrm{j}$ & $32.79 \mathrm{f}$ & 1.021 & $1.19 \mathrm{k}$ & $1.10 \mathrm{f}$ \\
\hline Amino power at $2 \mathrm{ml} / \mathrm{l}$ & $69.40 \mathrm{~d}$ & $73.04 \mathrm{c}$ & $71.22 \mathrm{~b}$ & $2.33 \mathrm{e}$ & $2.45 \mathrm{c}$ & $2.39 \mathrm{~b}$ \\
\hline Brassinolide at $50 \mathrm{mg} / \mathrm{l}$ & $61.00 \mathrm{~g}$ & $64.33 \mathrm{f}$ & $62.66 \mathrm{~d}$ & $2.05 \mathrm{~h}$ & $2.16 \mathrm{~g}$ & $2.11 \mathrm{~d}$ \\
\hline Humic acid at $5.0 \mathrm{ml} / \mathrm{l}$ & $66.09 \mathrm{e}$ & $69.89 \mathrm{~d}$ & 67.99 c & $2.22 \mathrm{f}$ & $2.35 \mathrm{~d}$ & $2.28 \mathrm{c}$ \\
\hline SA at 200 ppm & $43.41 \mathrm{i}$ & $48.79 \mathrm{~h}$ & $46.10 \mathrm{e}$ & $1.46 \mathrm{j}$ & $1.64 \mathrm{i}$ & $1.55 \mathrm{e}$ \\
\hline Seaweeds extract at $2 \mathrm{ml} / \mathrm{l}$ & $74.89 \mathrm{~b}$ & 77.56 a & $76.23 \mathrm{a}$ & $2.51 \mathrm{~b}$ & $2.60 \mathrm{a}$ & $2.56 \mathrm{a}$ \\
\hline \multirow[t]{2}{*}{ Mean (B) } & $57.51 \mathrm{~b}$ & $61.48 \mathrm{a}$ & & $1.93 \mathrm{~b}$ & $2.07 \mathrm{a}$ & \\
\hline & \multicolumn{6}{|c|}{ Second season } \\
\hline Control (tap water) & $31.09 \mathrm{i}$ & $37.02 \mathrm{~h}$ & $34.05 \mathrm{f}$ & $1.05 \mathrm{i}$ & $1.24 \mathrm{~h}$ & $1.15 f$ \\
\hline Amino power at $2 \mathrm{ml} / \mathrm{l}$ & $70.40 \mathrm{c}$ & $73.02 \mathrm{~b}$ & $71.71 \mathrm{~b}$ & $2.37 \mathrm{c}$ & $2.45 \mathrm{~b}$ & $2.41 \mathrm{~b}$ \\
\hline Brassinolide at $50 \mathrm{mg} / \mathrm{l}$ & $62.11 \mathrm{e}$ & $64.77 \mathrm{~d}$ & $63.44 \mathrm{~d}$ & $2.08 \mathrm{e}$ & $2.18 \mathrm{~d}$ & $2.13 \mathrm{~d}$ \\
\hline Humic acid at $5.0 \mathrm{ml} / \mathrm{l}$ & $65.81 \mathrm{~d}$ & $69.23 \mathrm{c}$ & 67.52 c & $2.21 \mathrm{~d}$ & $2.33 \mathrm{c}$ & $2.27 \mathrm{c}$ \\
\hline SA at 200 ppm & $44.01 \mathrm{~g}$ & $47.62 \mathrm{f}$ & $45.82 \mathrm{e}$ & $1.48 \mathrm{~g}$ & $1.60 \mathrm{f}$ & $1.54 \mathrm{e}$ \\
\hline Seaweeds extract at $2 \mathrm{ml} / \mathrm{l}$ & $74.08 \mathrm{~b}$ & $77.86 \mathrm{a}$ & $75.97 \mathrm{a}$ & $2.49 \mathrm{~b}$ & $2.58 \mathrm{a}$ & $2.53 \mathrm{a}$ \\
\hline Mean (B) & $57.92 \mathrm{~b}$ & 61.59 a & & $1.94 \mathrm{~b}$ & $2.06 \mathrm{a}$ & \\
\hline
\end{tabular}

AMF = Arbuscular mycorrhizal fungi; SA= Salicylic acid 


\section{Y.F.Y. Mohamed}

vegetative growth and seed yield characteristics as compared of uninoculated plants (control) of chia (Salvia hispanica L.) plants. Also, Ghatas (2020) indicated that, salicylic acid as foliar spray at $150 \mathrm{ppm}$ which gave slightly increases in the growth, seeds yield of Coriandrum sativum L. plant.

Amino acids contribute to the tolerance of plants against biotic and abiotic stresses either directly or indirectly by serving as precursors to secondary compounds and hormones. Additionally, the functions in the synthesis of other organic compounds, i.e. protein, amines, purines and pyrimidines, alkaloids, vitamins, enzymes, terpenoids and others (Behzad, 2011). The effect of brassinolide on growth vegetative parameters may be due to improve the cells growth, differentiation, enlargement and division, change membrane potentials and the metabolism of nucleic acids and proteins (Müssig, 2005 and Prins et al., 2010).

In this concern, humic acid has a great importance for the plant in terms of its effect on growth in addition to its clear importance to the soil as it works to improve the properties of the soil and increase the rate of microbial activity as it enhances the absorption of many nutrients as a chelating agent. It is known that humic materials increase the activity of root growth such as auxins, which in turn is reflected in the increased growth of the plant in various stages of growth, and leaf pigments (Berlyn and Russo, 1990; Frankenberger and Arshad, 1995; Graves et al., 2004; Pereira1 et al., 2019).

Salicylic acid (SA) plays a significant role in physiological and biological processes in plants and can be used to enhance the growth of plant under unfavorable environmental conditions (Karalija and Parić, 2017). Furthermore, the obtained increase of these traits could be seaweed products promote plant growth when applied in small quantities and are also referred to as metabolic enhancers. Seaweed extract contained components such as macroand micro element nutrients, amino acids, vitamins, cytokinins and auxins like growth substances in which affect cellular metabolism in treated plants leading to enhanced growth and crop yield (Zhang and Schmidt, 1997). Using of seaweeds lead to the activity of enzymes, and consequently, and increase in biological processes within the plant, which results in an increase in the growth and yield of the plant. (El-Boukhari et al., 2020).

\section{Oil yield parameters:}

According to data listed in Tables (6 and 7 ) it could be showed that, essential oil (\%), essential oil yield/plant (ml) and essential oil yield/feddan (l) of Dutch fennel plant were more affected by using growth stimulants and arbuscular mycorrhizal fungi (AMF) as well as their combinations treatments as compared to control plants in the first and second seasons. In this respect, in $1^{\text {st }}$ and $2^{\text {nd }}$ seasons seaweed extract at $2 \mathrm{ml} / \mathrm{l}$ or inoculum mycorrhizal fungi significantly gained the maximum values of theses parameters. However, the highest seeds oil percentage (2.22 and 2.24\%), the highest essential oil yield/plant (1.72 and $1.75 \mathrm{ml})$ and the maximum essential oil yield/feddan (57.90 and 58.69 l) were recorded by the combined treatment between seaweed extract combined and inoculum arbuscular mycorrhizal fungi (AMF) in the first and second seasons, respectively. Also, the combined treatment between seaweed extract combined and uninoculum arbuscular mycorrhizal fungi (AMF) ranked the second values in this context. Furthermore, using the combined treatment of amino acids or humic acid and inoculum arbuscular mycorrhizal fungi occupied the third values with non-significant differences between them in most cases. The minimum values of abovementioned oil parameters were obtained by control plants (tap water) especially uninoculum mycorrhizal fungi. In this concern, the results similar to those obtained by Maryam et al. (2014) on Ocimum basilicum, L., Mohamed et al. (2015) on Ocimum basilicum, L. cv. Genovese, Mohamed et al. (2016) on 
Table 6. Effect of some growth stimulants, mycorrhizal fungi and their combination treatments on essential oil (\%) and essential oil yield/plant (m) of Dutch fennel (Foeniculum vulgare Mill.), during 2018/2019 and 2019/2020 seasons.

\begin{tabular}{|c|c|c|c|c|c|c|}
\hline \multirow{3}{*}{ Growth stimulants } & \multicolumn{3}{|c|}{ Essential oil (\%) } & \multicolumn{3}{|c|}{ Essential oil yield/plant (ml) } \\
\hline & \multirow[b]{2}{*}{$\begin{array}{l}\text { Uninoculum } \\
\text { AMF }\end{array}$} & \multicolumn{4}{|c|}{ First season } & \multirow[b]{2}{*}{ Mean (A) } \\
\hline & & $\begin{array}{l}\text { Inoculum } \\
\text { AMF }\end{array}$ & Mean (A) & $\begin{array}{c}\text { Uninoculum } \\
\text { AMF }\end{array}$ & $\begin{array}{l}\text { Inoculum } \\
\text { AMF }\end{array}$ & \\
\hline $\begin{array}{l}\text { Control (tap water) } \\
\text { (tap }\end{array}$ & $1.25 \mathrm{j}$ & $1.35 \mathrm{i}$ & $1.30 \mathrm{e}$ & $0.38 \mathrm{k}$ & $0.47 \mathrm{j}$ & $0.43 \mathrm{f}$ \\
\hline Amino power at $2 \mathrm{ml} / \mathbf{l}$ & $1.88 \mathrm{f}$ & $1.91 \mathrm{e}$ & $1.90 \mathrm{c}$ & $1.31 \mathrm{~d}$ & $1.39 \mathrm{c}$ & $1.35 \mathrm{~b}$ \\
\hline Brassinolide at $50 \mathrm{mg} / \mathrm{l}$ & $1.79 \mathrm{~h}$ & $1.82 \mathrm{~g}$ & $1.81 \mathrm{~d}$ & $1.09 \mathrm{~g}$ & $1.17 \mathrm{f}$ & $1.13 \mathrm{~d}$ \\
\hline Humic acid at $5.0 \mathrm{ml} / \mathrm{l}$ & $1.94 \mathrm{~d}$ & $1.98 \mathrm{c}$ & $1.96 \mathrm{~b}$ & $1.28 \mathrm{e}$ & $1.38 \mathrm{c}$ & $1.33 \mathrm{c}$ \\
\hline SA at $200 \mathrm{ppm}$ & $1.79 \mathrm{~h}$ & $1.82 \mathrm{~g}$ & $1.80 \mathrm{~d}$ & $0.77 \mathrm{i}$ & $0.89 \mathrm{~h}$ & $0.83 \mathrm{e}$ \\
\hline Seaweeds extract at $2 \mathrm{ml} / \mathrm{l}$ & $2.03 \mathrm{~b}$ & $2.22 \mathrm{a}$ & $2.13 \mathrm{a}$ & $1.52 \mathrm{~b}$ & $1.72 \mathrm{a}$ & $1.62 \mathrm{a}$ \\
\hline \multirow[t]{2}{*}{ Mean (B) } & $1.78 \mathrm{~b}$ & $1.85 \mathrm{a}$ & & $1.06 \mathrm{~b}$ & $1.17 \mathrm{a}$ & \\
\hline & \multicolumn{6}{|c|}{ Second season } \\
\hline Control (tap water) & $1.29 \mathrm{j}$ & $1.37 \mathrm{i}$ & $1.33 \mathrm{e}$ & $0.40 \mathrm{j}$ & $0.51 \mathrm{i}$ & $0.45 \mathrm{e}$ \\
\hline Amino power at $2 \mathrm{ml} / \mathrm{l}$ & $1.91 \mathrm{ef}$ & 1.94 de & $1.93 \mathrm{c}$ & $1.34 \mathrm{~d}$ & $1.43 \mathrm{c}$ & $1.38 \mathrm{~b}$ \\
\hline Brassinolide at $50 \mathrm{mg} / \mathrm{l}$ & $1.81 \mathrm{gh}$ & $1.86 \mathrm{fg}$ & $1.84 \mathrm{~d}$ & $1.13 \mathrm{f}$ & $1.21 \mathrm{e}$ & $1.17 \mathrm{c}$ \\
\hline Humic acid at $5.0 \mathrm{ml} / \mathrm{l}$ & $1.96 \mathrm{~cd}$ & $2.03 \mathrm{~b}$ & $1.99 \mathrm{~b}$ & $1.29 \mathrm{~d}$ & $1.40 \mathrm{c}$ & $1.35 \mathrm{~b}$ \\
\hline SA at 200 ppm & $1.80 \mathrm{~h}$ & $1.82 \mathrm{gh}$ & $1.81 \mathrm{~d}$ & $0.79 \mathrm{~h}$ & $0.87 \mathrm{~g}$ & $0.83 \mathrm{~d}$ \\
\hline Seaweeds extract at $2 \mathrm{ml} / \mathrm{l}$ & $2.01 \mathrm{bc}$ & $2.24 \mathrm{a}$ & $2.13 \mathrm{a}$ & $1.49 \mathrm{~b}$ & $1.75 \mathrm{a}$ & $1.62 \mathrm{a}$ \\
\hline Mean (B) & $1.80 \mathrm{~b}$ & $1.88 \mathrm{a}$ & & $1.07 \mathrm{~b}$ & $1.19 \mathrm{a}$ & \\
\hline
\end{tabular}

AMF = Arbuscular mycorrhizal fungi; SA= Salicylic acid

Table 7. Effect of some growth stimulants, mycorrhizal fungi and their combination treatments on essential oil yield/feddan (l) and chlorophyll a mg/g f.w. of Dutch fennel (Foeniculum vulgare Mill.), during 2018/2019 and 2019/2020 seasons.

\begin{tabular}{|c|c|c|c|c|c|c|}
\hline \multirow{3}{*}{ Growth stimulants } & \multicolumn{3}{|c|}{ Essential oil yield/feddan (l) } & \multicolumn{3}{|c|}{ Chlorophyll a mg/g f.w. } \\
\hline & \multicolumn{6}{|c|}{ First season } \\
\hline & $\begin{array}{c}\text { Uninoculum } \\
\text { AMF }\end{array}$ & $\begin{array}{l}\text { Inoculum } \\
\text { AMF }\end{array}$ & Mean (A) & $\begin{array}{l}\text { Uninoculum } \\
\text { AMF }\end{array}$ & $\begin{array}{l}\text { Inoculum } \\
\text { AMF }\end{array}$ & Mean (A) \\
\hline Control (tap water) & $12.77 \mathrm{k}$ & $15.79 \mathrm{j}$ & $14.28 \mathrm{e}$ & 0.6981 & $0.713 \mathrm{k}$ & $0.705 \mathrm{f}$ \\
\hline Amino power at $2 \mathrm{ml} / \mathrm{l}$ & $44.02 \mathrm{~d}$ & $46.82 \mathrm{c}$ & $45.42 \mathrm{~b}$ & $0.898 \mathrm{f}$ & $1.010 \mathrm{e}$ & $0.954 \mathrm{c}$ \\
\hline Brassinolide at 50 mg/l & $36.74 \mathrm{~g}$ & $39.31 \mathrm{f}$ & 38.03c & $0.824 \mathrm{i}$ & $0.865 \mathrm{~h}$ & $0.844 \mathrm{~d}$ \\
\hline Humic acid at $5.0 \mathrm{ml} / \mathrm{l}$ & $43.01 \mathrm{e}$ & $46.59 \mathrm{c}$ & $44.80 \mathrm{~b}$ & $1.030 \mathrm{~d}$ & $1.100 \mathrm{c}$ & $1.065 \mathrm{~b}$ \\
\hline SA at $200 \mathrm{ppm}$ & $25.98 \mathrm{i}$ & $29.79 \mathrm{~h}$ & $27.89 \mathrm{~d}$ & $0.796 \mathrm{j}$ & $0.878 \mathrm{~g}$ & $0.837 \mathrm{e}$ \\
\hline Seaweeds extract at $2 \mathrm{ml} / \mathrm{l}$ & $51.07 \mathrm{~b}$ & $57.90 \mathrm{a}$ & $54.49 \mathrm{a}$ & $1.157 \mathrm{a}$ & $1.142 \mathrm{~b}$ & $1.149 \mathrm{a}$ \\
\hline \multirow[t]{2}{*}{ Mean (B) } & $35.60 \mathrm{~b}$ & 39.37 a & & $0.900 \mathrm{~b}$ & $0.951 \mathrm{a}$ & \\
\hline & \multicolumn{6}{|c|}{ Second season } \\
\hline Control (tap water) & $13.44 \mathrm{k}$ & $17.03 \mathrm{j}$ & $15.23 \mathrm{f}$ & $0.708 \mathrm{e}$ & 0.717 de & $0.713 \mathrm{~b}$ \\
\hline Amino power at $2 \mathrm{ml} / \mathbf{l}$ & $45.02 \mathrm{~d}$ & $47.94 \mathrm{c}$ & $46.48 \mathrm{~b}$ & $0.994 \mathrm{a}-\mathrm{d}$ & $0.699 \mathrm{e}$ & $0.846 \mathrm{~b}$ \\
\hline Brassinolide at $50 \mathrm{mg} / \mathrm{l}$ & $37.86 \mathrm{~g}$ & $40.54 \mathrm{f}$ & $39.20 \mathrm{~d}$ & $0.835 \mathrm{~b}-\mathrm{e}$ & 0.870 a-e & $0.853 \mathrm{~b}$ \\
\hline Humic acid at $5.0 \mathrm{ml} / \mathrm{l}$ & $43.46 \mathrm{e}$ & $47.15 \mathrm{c}$ & $45.31 \mathrm{c}$ & $1.043 \mathrm{a}-\mathrm{c}$ & $1.102 \mathrm{ab}$ & $1.073 \mathrm{a}$ \\
\hline SA at 200 ppm & $26.54 \mathrm{i}$ & $29.12 \mathrm{~h}$ & $27.83 \mathrm{e}$ & 0.813 c-e & 0.884 a-e & $0.849 \mathrm{~b}$ \\
\hline Seaweeds extract at $2 \mathrm{ml} / \mathrm{l}$ & $49.95 \mathrm{~b}$ & $58.69 \mathrm{a}$ & $54.32 \mathrm{a}$ & $1.122 \mathrm{a}$ & $1.146 \mathrm{a}$ & $1.134 \mathrm{a}$ \\
\hline Mean (B) & $36.4 \mathrm{~b}$ & 40.08 a & & 0.919 a & $0.903 \mathrm{a}$ & \\
\hline
\end{tabular}

AMF = Arbuscular mycorrhizal fungi; SA= Salicylic acid 
Ocimum basilicum, L. cv. Genovese demonstrated that, essential oil percentage in leaves gave the greatest values when plants treated with the combined treatments of seaweeds extract $(2 \mathrm{ml} / \mathrm{l})$ or amino acids (1 $\mathrm{g} / \mathrm{l})$ and boron (100 ppm). Mansori et al. (2019) demonstrated that, the application of seaweeds extracts enhances the oil parameters of Salvia officinalis plant. Mady (2020) on Dutch fennel (Foeniculum vulgare Mill.) suggested that, the lowest values were obtained with plants treated by T5 (biofertilizers only) as compared to the other treatments in both seasons.

\section{Chemical composition determinations:}

Data presented in Tables (7, 8, 9 and 10) demonstrated that chemical composition i.e. (chlorophyll a, b and carotenoids, N, P, K and total carbohydrates \%) were increased by foliar spray of all growth stimulants when compared to untreated (tap water). However, the maximum chemical composition values were registered by seaweed extract at $2 \mathrm{ml} / \mathrm{l}$ treatment in the two seasons. Moreover, in both seasons, humic acid at $5.0 \mathrm{ml} / \mathrm{l}$ and amino acid at $2 \mathrm{ml} / \mathrm{l}$ score the second and third values of these parameters in both seasons, respectively. Regarding mycorrhizal fungi treatments, data in the same Tables suggested that inoculum mycorrhizal fungi treatment significantly increased these chemical parameters describe above of Dutch fennel plant when compared to uninoculum mycorrhizal fungi with the exception of chlorophyll a in the second season only. Whereas, the highest slightly increases of chlorophyll a (mg/g f.w.) was registered by uninoculum mycorrhizal fungi as compared inoculum mycorrhizal fungi with non-significant differences between them. Additionally, the highest values of aforementioned chemical parameters were recorded by using the combined treatment between seaweed extract with inoculum arbuscular mycorrhizal fungi (AMF) with the exception of chlorophyll a (mg/g f.w.) in the first season only. Whereas, the first season the highest values of chlorophyll a (mg/g f.w.) was scored by seaweed extract with uninoculum arbuscular mycorrhizal

Table 8. Effect of some growth stimulants, mycorrhizal fungi and their combination treatments on chlorophyll b (mg/g f.w.) and carotenoids (mg/g f.w.) of Dutch fennel (Foeniculum vulgare Mill.), during 2018/2019 and 2019/2020 seasons.

Chlorophyll b mg/g f.w.

First season

Growth stimulants

\begin{tabular}{|c|c|c|c|c|c|c|}
\hline Grown stimtulats & $\begin{array}{c}\text { Uninoculum } \\
\text { AMF }\end{array}$ & $\begin{array}{l}\text { Inoculum } \\
\text { AMF }\end{array}$ & Mean (A) & $\begin{array}{c}\text { Uninoculum } \\
\text { AMF }\end{array}$ & $\begin{array}{c}\text { Inoculum } \\
\text { AMF }\end{array}$ & Mean (A) \\
\hline Control (tap water) & $0.305 \mathrm{j}$ & $0.322 \mathrm{i}$ & $0.313 \mathrm{f}$ & $0.136 \mathrm{j}$ & $0.146 \mathrm{i}$ & $0.141 \mathrm{f}$ \\
\hline Amino power at $2 \mathrm{ml} / \mathbf{l}$ & $0.455 \mathrm{e}$ & $0.470 \mathrm{~d}$ & $0.463 \mathrm{c}$ & $0.261 \mathrm{e}$ & $0.267 \mathrm{~d}$ & $0.264 \mathrm{c}$ \\
\hline Brassinolide at $50 \mathrm{mg} / \mathrm{l}$ & $0.440 \mathrm{f}$ & $0.457 \mathrm{e}$ & $0.449 \mathrm{~d}$ & $0.250 \mathrm{f}$ & $0.256 \mathrm{e}$ & $0.253 \mathrm{~d}$ \\
\hline Humic acid at $5.0 \mathrm{ml} / \mathbf{l}$ & $0.488 \mathrm{c}$ & $0.495 \mathrm{~b}$ & $0.492 \mathrm{~b}$ & $0.269 \mathrm{~cd}$ & $0.273 \mathrm{c}$ & $0.271 \mathrm{~b}$ \\
\hline SA at 200 ppm & $0.390 \mathrm{~h}$ & $0.399 \mathrm{~g}$ & $0.394 \mathrm{e}$ & $0.192 \mathrm{~h}$ & $0.200 \mathrm{~g}$ & $0.196 \mathrm{e}$ \\
\hline Seaweeds extract at $2 \mathrm{ml} / \mathrm{l}$ & $0.496 \mathrm{~b}$ & $0.515 \mathrm{a}$ & $0.505 \mathrm{a}$ & $0.282 \mathrm{~b}$ & $0.290 \mathrm{a}$ & $0.286 \mathrm{a}$ \\
\hline \multirow[t]{2}{*}{ Mean (B) } & $0.429 \mathrm{~b}$ & $0.443 \mathrm{a}$ & & $0.232 \mathrm{~b}$ & 0.239 a & \\
\hline & \multicolumn{6}{|c|}{ Second season } \\
\hline Control (tap water) & $0.310 \mathrm{j}$ & $0.325 \mathrm{i}$ & $0.318 \mathrm{f}$ & $0.140 \mathrm{j}$ & $0.149 \mathrm{i}$ & $0.144 \mathrm{f}$ \\
\hline Amino power at $2 \mathrm{ml} / \mathbf{l}$ & $0.460 \mathrm{e}$ & $0.472 \mathrm{~d}$ & $0.466 \mathrm{c}$ & $0.261 \mathrm{e}$ & $0.270 \mathrm{~d}$ & $0.266 \mathrm{c}$ \\
\hline Brassinolide at $50 \mathrm{mg} / \mathrm{l}$ & $0.448 \mathrm{f}$ & $0.460 \mathrm{e}$ & $0.454 \mathrm{~d}$ & $0.248 \mathrm{f}$ & $0.258 \mathrm{e}$ & $0.253 \mathrm{~d}$ \\
\hline Humic acid at $5.0 \mathrm{ml} / \mathrm{l}$ & 0.489 c & $0.500 \mathrm{~b}$ & $0.495 \mathrm{~b}$ & $0.269 \mathrm{~d}$ & $0.278 \mathrm{c}$ & $0.274 \mathrm{~b}$ \\
\hline SA at 200 ppm & $0.396 \mathrm{~h}$ & $0.405 \mathrm{~g}$ & $0.400 \mathrm{e}$ & $0.198 \mathrm{~h}$ & $0.208 \mathrm{~g}$ & $0.203 \mathrm{e}$ \\
\hline Seaweeds extract at $2 \mathrm{ml} / \mathrm{l}$ & 0.492 c & $0.520 \mathrm{a}$ & $0.506 \mathrm{a}$ & $0.283 \mathrm{~b}$ & $0.293 \mathrm{a}$ & $0.288 \mathrm{a}$ \\
\hline Mean (B) & $0.432 \mathrm{~b}$ & $0.447 \mathrm{a}$ & & $0.233 \mathrm{~b}$ & $0.243 \mathrm{a}$ & \\
\hline
\end{tabular}

Carotenoids mg/g f.w.

\section{-}


Table 9. Effect of some growth stimulants, mycorrhizal fungi and their combination treatments on $\mathbf{N} \%$ and $P \%$ of Dutch fennel (Foeniculum vulgare Mill.), during 2018/2019 and 2019/2020 seasons.

\begin{tabular}{|c|c|c|c|c|c|c|}
\hline \multirow{3}{*}{ Growth stimulants } & \multicolumn{3}{|c|}{ N \% } & \multicolumn{3}{|c|}{$\mathbf{P} \%$} \\
\hline & \multicolumn{6}{|c|}{ First season } \\
\hline & $\begin{array}{l}\text { Uninoculum } \\
\text { AMF }\end{array}$ & $\begin{array}{l}\text { Inoculum } \\
\text { AMF }\end{array}$ & Mean (A) & $\begin{array}{l}\text { Uninoculum } \\
\text { AMF }\end{array}$ & $\begin{array}{l}\text { Inoculum } \\
\text { AMF }\end{array}$ & Mean (A) \\
\hline Control (tap water) & $1.68 \mathrm{k}$ & $1.78 \mathrm{j}$ & $1.73 \mathrm{f}$ & $0.214 \mathrm{j}$ & $0.220 \mathrm{i}$ & $0.217 \mathrm{f}$ \\
\hline Amino power at 2ml/l & $2.71 \mathrm{e}$ & $2.75 \mathrm{~d}$ & $2.73 \mathrm{c}$ & $0.271 \mathrm{e}$ & $0.276 \mathrm{~d}$ & $0.273 \mathrm{c}$ \\
\hline Brassinolide at $50 \mathrm{mg} / \mathrm{l}$ & $2.47 \mathrm{~g}$ & $2.58 \mathrm{f}$ & $2.53 \mathrm{~d}$ & $0.265 \mathrm{f}$ & $0.272 \mathrm{e}$ & $0.268 \mathrm{~d}$ \\
\hline Humic acid at $5.0 \mathrm{ml} / \mathrm{l}$ & $2.78 \mathrm{c}$ & $2.86 \mathrm{~b}$ & $2.82 \mathrm{~b}$ & 0.290 c & $0.297 \mathrm{~b}$ & $0.293 \mathrm{~b}$ \\
\hline SA at $200 \mathrm{ppm}$ & $1.90 \mathrm{i}$ & $2.08 \mathrm{~h}$ & $1.99 \mathrm{e}$ & $0.242 \mathrm{~h}$ & $0.250 \mathrm{~g}$ & $0.246 \mathrm{e}$ \\
\hline Seaweeds extract at $2 \mathrm{ml} / \mathrm{l}$ & $2.79 \mathrm{c}$ & $2.88 \mathrm{a}$ & $2.84 \mathrm{a}$ & $0.296 \mathrm{~b}$ & $0.301 \mathrm{a}$ & 0.299 a \\
\hline \multirow[t]{2}{*}{ Mean (B) } & $2.39 \mathrm{~b}$ & $2.49 \mathrm{a}$ & & $0.263 \mathrm{~b}$ & 0.269 a & \\
\hline & \multicolumn{6}{|c|}{ Second season } \\
\hline Control (tap water) & $1.72 \mathrm{l}$ & $1.80 \mathrm{k}$ & $1.76 \mathrm{f}$ & $0.216 \mathrm{i}$ & $0.220 \mathrm{~h}$ & $0.218 \mathrm{e}$ \\
\hline Amino power at $2 \mathrm{ml} / \mathrm{l}$ & $2.68 \mathrm{f}$ & $2.76 \mathrm{e}$ & $2.72 \mathrm{c}$ & $0.271 \mathrm{e}$ & $0.275 \mathrm{~d}$ & $0.273 \mathrm{c}$ \\
\hline Brassinolide at 50 mg/l & $2.50 \mathrm{~h}$ & $2.61 \mathrm{~g}$ & $2.56 \mathrm{~d}$ & 0.269 e & 0.272 de & $0.271 \mathrm{c}$ \\
\hline Humic acid at $5.0 \mathrm{ml} / \mathrm{l}$ & $2.77 \mathrm{~d}$ & $2.88 \mathrm{~b}$ & $2.83 \mathrm{~b}$ & 0.290 c & $0.298 \mathrm{~b}$ & $0.294 \mathrm{~b}$ \\
\hline SA at $200 \mathrm{ppm}$ & $1.94 \mathrm{~g}$ & $2.13 \mathrm{i}$ & $2.04 \mathrm{e}$ & $0.243 \mathrm{~g}$ & $0.252 \mathrm{f}$ & $0.248 \mathrm{~d}$ \\
\hline Seaweeds extract at $2 \mathrm{ml} / \mathrm{l}$ & $2.79 \mathrm{c}$ & $2.91 \mathrm{a}$ & $2.85 \mathrm{a}$ & $0.297 \mathrm{~b}$ & 0.306 a & $0.302 \mathrm{a}$ \\
\hline Mean (B) & $2.40 \mathrm{~b}$ & $2.52 \mathrm{a}$ & & $0.264 \mathrm{~b}$ & $0.271 \mathrm{a}$ & \\
\hline
\end{tabular}

AMF = Arbuscular mycorrhizal fungi; SA= Salicylic acid

Table 10. Effect of some growth stimulants, mycorrhizal fungi and their combination treatments on $\mathrm{K} \%$ and total carbohydrates \% of Dutch fennel (Foeniculum vulgare Mill.), during 2018/2019 and 2019/2020 seasons.

\begin{tabular}{|c|c|c|c|c|c|c|}
\hline \multirow{3}{*}{ Growth stimulants } & \multicolumn{3}{|c|}{ K \% } & \multicolumn{3}{|c|}{ Total carbohydrates \% } \\
\hline & \multicolumn{6}{|c|}{ First season } \\
\hline & $\begin{array}{c}\text { Uninoculum } \\
\text { AMF }\end{array}$ & $\begin{array}{l}\text { Inoculum } \\
\text { AMF }\end{array}$ & Mean (A) & $\begin{array}{c}\text { Uninoculum } \\
\text { AMF }\end{array}$ & $\begin{array}{l}\text { Inoculum } \\
\text { AMF }\end{array}$ & Mean (A) \\
\hline Control (tap water) & 1.181 & $1.26 \mathrm{k}$ & $1.22 \mathrm{f}$ & $15.96 \mathrm{j}$ & $16.96 \mathrm{i}$ & $16.46 \mathrm{f}$ \\
\hline Amino power at $2 \mathrm{ml} / \mathrm{l}$ & $1.95 \mathrm{f}$ & $2.01 \mathrm{e}$ & $1.98 \mathrm{c}$ & $18.77 \mathrm{fg}$ & 19.14 ef & $18.96 \mathrm{~d}$ \\
\hline Brassinolide at $50 \mathrm{mg} / \mathrm{l}$ & $1.79 \mathrm{~h}$ & $1.85 \mathrm{~g}$ & $1.82 \mathrm{~d}$ & 19.41 de & $19.87 \mathrm{~d}$ & $19.64 \mathrm{c}$ \\
\hline Humic acid at $5.0 \mathrm{ml} / \mathrm{l}$ & $2.09 \mathrm{~d}$ & $2.18 \mathrm{c}$ & $2.13 \mathrm{~b}$ & $19.93 \mathrm{~d}$ & $21.22 \mathrm{c}$ & $20.57 \mathrm{~b}$ \\
\hline SA at 200 ppm & $1.49 \mathrm{~g}$ & $1.60 \mathrm{i}$ & $1.54 \mathrm{e}$ & $18.00 \mathrm{~h}$ & $18.49 \mathrm{gh}$ & $18.24 \mathrm{e}$ \\
\hline Seaweeds extract at $2 \mathrm{ml} / \mathrm{l}$ & $2.30 \mathrm{~b}$ & 2.36 a & $2.33 \mathrm{a}$ & $22.10 \mathrm{~b}$ & $23.25 \mathrm{a}$ & 22.67 a \\
\hline \multirow[t]{2}{*}{ Mean (B) } & $1.80 \mathrm{~b}$ & $1.88 \mathrm{a}$ & & $19.03 \mathrm{~b}$ & $19.82 \mathrm{a}$ & \\
\hline & \multicolumn{6}{|c|}{ Second season } \\
\hline Control (tap water) & $1.22 \mathrm{k}$ & $1.28 \mathrm{j}$ & $1.25 \mathrm{f}$ & $16.26 \mathrm{~g}$ & $16.81 \mathrm{fg}$ & $16.53 \mathrm{e}$ \\
\hline Amino power at $2 \mathrm{ml} / \mathrm{l}$ & $1.92 \mathrm{f}$ & $2.01 \mathrm{e}$ & $1.96 \mathrm{c}$ & $17.81 \mathrm{e}$ & $19.07 \mathrm{~d}$ & $18.44 \mathrm{~d}$ \\
\hline Brassinolide at $50 \mathrm{mg} / \mathrm{l}$ & $1.81 \mathrm{~g}$ & $1.85 \mathrm{~g}$ & $1.83 \mathrm{~d}$ & $19.95 \mathrm{~cd}$ & 20.83 bc & 20.39 c \\
\hline Humic acid at $5.0 \mathrm{ml} / \mathrm{l}$ & $2.12 \mathrm{~d}$ & $2.22 \mathrm{c}$ & $2.17 \mathrm{~b}$ & 20.39 c & $21.70 \mathrm{~b}$ & $21.05 \mathrm{~b}$ \\
\hline SA at $200 \mathrm{ppm}$ & $1.47 \mathrm{i}$ & $1.62 \mathrm{~h}$ & $1.55 \mathrm{e}$ & 17.58 ef & $19.11 \mathrm{~d}$ & $18.34 \mathrm{~d}$ \\
\hline Seaweeds extract at $2 \mathrm{ml} / \mathrm{l}$ & $2.29 \mathrm{~b}$ & $2.38 \mathrm{a}$ & $2.34 \mathrm{a}$ & $21.55 \mathrm{~b}$ & $23.41 \mathrm{a}$ & $22.48 \mathrm{a}$ \\
\hline Mean (B) & $1.80 \mathrm{~b}$ & $1.90 \mathrm{a}$ & & $18.92 \mathrm{~b}$ & $21.15 \mathrm{a}$ & \\
\hline
\end{tabular}

AMF = Arbuscular mycorrhizal fungi; SA= Salicylic acid 
fungi (AMF). Also, the combined treatment between humic acid at $5.0 \mathrm{ml} / \mathrm{l}$ or amino acid at $2 \mathrm{ml} / \mathrm{l}$ and inoculum mycorrhizal fungi recorded highly increments of these parameters. In contrast, the minimum values of abovementioned parameters were obtained by control plants (tap water) or salicylic acid (SA) at 200 ppm especially uninoculum mycorrhizal fungi, in ascending order and in the both seasons.

The abovementioned results of different treatments are nearly similar to those obtained by Maryam et al. (2014) on Ocimum basilicum, L., Mohamed et al. (2015) on basil plant, Mohamed et al. (2016) on Ocimum basilicum, L. cv. Genovese. ElKhateeb (2017) on Majorana hortensis plant, Ibrahim and Helaly (2017) on fenugreek plants, Mansori et al. (2019) demonstrated that, the application of seaweeds extracts enhances the chemical composition of Salvia officinalis plant., Moghith (2019) stated that, the maximum significant increases of chemical composition of chia (Salvia hispanica L.) plants was recorded by inoculum mycorrhizal fungi as compared of uninoculated plants (control) in both seasons. Furthermore Ghatas (2020) on Coriandrum sativum L. plant.

\section{Essential oil constituents:}

The GLC analysis of Dutch fennel essential oil as indicated in Table (11) and Figs. (1-4) suggested the presence of ten compounds with the presence of anethole as the main components, followed by estragole as well as $\alpha$-pinene, sabinene, ß-pinene, myrcene, 1,8 cineole, fenchone, estragole, trans-anethole, ß-caryophyllene and tetracosamethyl-cyclododecasiloxane. The master component of Dutch fennel seeds volatile oil was trans-anethole. However, the highest value of anethole $(42.27 \%)$ was listed by seaweeds extract at $2 \mathrm{ml} / \mathrm{l}+\mathrm{AMF}$, followed by humic acid at $5.0 \mathrm{ml} / \mathrm{l}+\mathrm{AMF}$ (40.21\%). While, the maximum percentage of Estragole (32.20\%) occurred with seaweeds extract at $2 \mathrm{ml} / \mathrm{l}+\mathrm{AMF}$ in comparison of other treatments. In addition, the combined treatment of seaweeds extract at $2 \mathrm{ml} / \mathrm{l}+$ AMF gave the richest percentage

Table 11. Influence of various treatments on essential oil composition of Dutch fennel (Foeniculum vulgare Mill.) plant, during the second season 2019/2020.

\begin{tabular}{llcccc}
\hline $\begin{array}{c}\text { Peak } \\
\text { No. }\end{array}$ & \multicolumn{1}{c}{$\begin{array}{c}\text { Component } \\
\text { name }\end{array}$} & $\begin{array}{c}\text { Control } \\
\text { (tap water) }\end{array}$ & $\begin{array}{c}\text { Amino acid } \\
\text { at 2 ml// + AMF }\end{array}$ & $\begin{array}{c}\text { Humic acid } \\
\text { at 5.0 ml// + AMF }\end{array}$ & $\begin{array}{c}\text { Seaweeds extract } \\
\text { at 2 ml// + AMF }\end{array}$ \\
\hline $\mathbf{1}$ & $\boldsymbol{\alpha}$-Pinene & 9.34 & 5.25 & 4.41 & 0.58 \\
$\mathbf{2}$ & Sabinene & 1.29 & 1.44 & 1.42 & 1.47 \\
$\mathbf{3}$ & ß-Pinene & 1.40 & 0.95 & 0.99 & 0.80 \\
$\mathbf{4}$ & Myrcene & 10.51 & 8.70 & 8.82 & 12.14 \\
$\mathbf{5}$ & $\mathbf{1 , 8}$ cineole & 2.16 & 6.27 & 6.34 & 1.89 \\
$\mathbf{6}$ & Fenchone & 3.69 & 4.02 & 3.80 & 3.57 \\
$\mathbf{7}$ & Estragole & 27.69 & 29.11 & 30.16 & 32.20 \\
$\mathbf{8}$ & Trans-anethole & 36.50 & 39.15 & 40.21 & 42.27 \\
$\mathbf{9}$ & B-caryophyllene & 2.57 & 2.11 & 1.92 & 2.29 \\
$\mathbf{1 0}$ & Tetracosamethyl- & & & & 0.51 \\
& cyclododecasiloxane & 0.76 & - & - & 97.72 \\
- & Total identified & 95.91 & 96.90 & 98.97 & 2.28 \\
$*$ & Unknown & 4.09 & 3.10 & 1.03 & 100.00 \\
& \multicolumn{1}{c}{ Total } & 100.00 & 100.00 & 100.00 &
\end{tabular}

AMF = Arbuscular mycorrhizal fungi 
Scientific J. Flowers \& Ornamental Plants, 7(3):303-319 (2020)
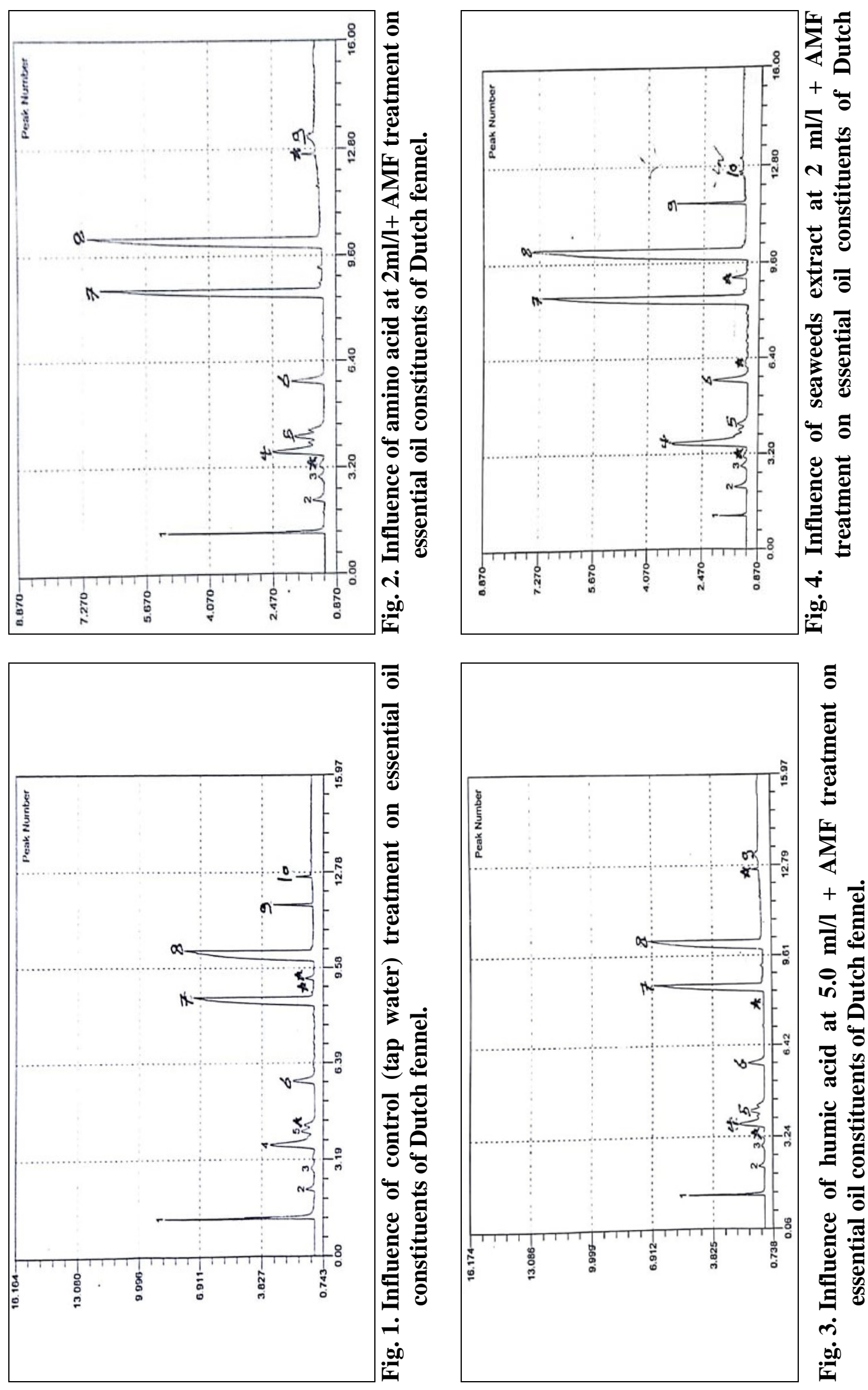
of myrcene (12.14\%). In contrast, different treatments caused decreases in the percentage of $\alpha$-pinene from (9.34\%) in control reaches to the minimum values $(0.58 \%)$ of seaweeds extract at $2 \mathrm{ml} / \mathrm{l}+$ AMF. Finally, humic acid at $5.0 \mathrm{ml} / \mathrm{l}+\mathrm{AMF}$ score the large values of 1,8 cineole (6.34\%). In this regard, El Laban et al. (2017) on Dutch fennel, the results showed that, the main chemical constituents i.e. transanethole, estragole, fenchone, limonene, alpha-pinene. Mady (2020) on Dutch fennel (Foeniculum vulgare Mill.) stated that, the presence of 16 compounds with the presence of anethole as the main components, followed by estragole.

\section{CONCLUSION}

Generally, it is preferable from the results mentioned above that, the tallest plant, the highest values of branches number and the heaviest fresh and dry weights, were scored by spraying Dutch fennel plant with seaweed extract combined with superior for the inoculum mycorrhizal fungi in the two seasons (Tables, 2 and 3). Using growth stimulant treatments progressively increased the seeds yield parameters i.e. number of umbels/plant, weight of 1000 seed (g), seeds yield/plant (g) and seeds yield/feddan (ton) especially the inoculum mycorrhizal fungi. In this respect, the richest leaf chlorophyll a, $\mathrm{b}$ and caroteniads, $\mathrm{N}, \mathrm{P}, \mathrm{K}$ and total carbohydrate were resuled by seaweed extract combined with the inoculum mycorrhizal fungi as well as their combinations in most cases (Tables, 7, 8, 9 and 10). Hence, the afore enhancment of different parameters of Dutch fennel plant growth, greatly affected were reflexed the superior of essential oil (\%) and their constituents, as well (Tables 7, 11 and Figs. 1-4). Finally, it could be recommended that the combinations of seaweed extract at $2 \mathrm{ml} / \mathrm{l}$ and inoculum arbuscular mycorrhizal fungi (AMF) could achieved the largest growth, seeds yield, chemical constituents and oil productivity of Dutch fennel (Foeniculum vulgare Mill. spp. vulgare).

\section{REFERENCES}

Abd El-Aleem, W.; Hendawy, S.F.; Hamed, E. S. and Toaima, W.I.M. (2017). Effect of planting dates, organic fertilization and foliar spray of algae extract on productivity of Dutch fennel plants under Sinai conditions. Journal of Medicinal Plants Studies, 5(3):327-334.

Badgujar, S.B.; Patel, V.V. and Bandivdekar, A.H. (2014). Foeniculum vulgare Mill, A review of its botany, phytochemistry, pharmacology, contemporary application, and toxicology. Biomed. Research Journal, 1:1-21.

Badr El-Din S.M.S; Attia, M. and AboSedera, S.A. (1999). Evaluation of several substrates for mass multiplication of arbuscular mycorrhizal (AM) fungi grown on onion. Egyptian Journal of Microbiology, 34:57-61.

Behzad, S. (2011). Effects of amino acids and irrigation interrupted on some characteristics in flixweld (Descurainia sophia L.). Proc. International Conference on Biology, Environment and Chemistry., IACSIT Press, Singapore, 1:375-378.

Bera, A.K.; Pramanik, K. and Mandal, B. (2014). Response of biofertilizers and homo-brassinolide on growth, yield and oil content of sunflower (Helianthus annuus L.). African Journal of Agricultural Research, 9(48):3494-3503.

Berlyn, G.P. and Russo, R.O. (1990). The use of organic biostimulants to promote root growth. Below Ground Ecol., 2:1213.

Black, C.A.; Evans, D.O.; Ensminger, LE.; White, J.L.; Clark, F.E. and Dinauer, R.C. (1982). Methods of Soil Analysis, Part 2: Chemical and Microbiological Properties, $2^{\text {nd }}$ ed. Soil Sci. Soc. of Am. Inc. Publ., Madison, Wisconsin, U.S.A., $1159 \mathrm{p}$.

Blumenthal, M.; Goldberg, A. and Brinckmann, J. (2000). Herbal Medicine: Expanded Commission E Monographs. 
American Botanical Council. Austin, TX. 519 p.

British Pharmacopoeia (1980). Volatile Oil in Drugs, vol. 2. The Univ. Press, Cambridge, England, 1196 p.

Chaplin, M.F. and Kennedy, J.F. (1994). Carbohydrate Analysis, $2^{\text {nd }}$ ed. Oxford University Press, New York., 344 p.

Choi, E.M. and Hwang, J.K. (2004). Antiinflammatory, analgesic and antioxidant activities of the fruit of Foeniculum vulgare. Fitoterapia, 75:557-565.

Coorey, R.; Grant, A. and Jayasena, V. (2012). Effects of chia flour incorporation on the nutritive quality and consumer acceptance of chips. Journal of Food Research, 1(4):85-94.

Crouch, I.J. and VanStaden, J. (1994). Commercial seaweed products as bio stimulants in horticulture. Journal of Home and Consumer Horticulture 1:1976.

Duncan, D.B. (1955). Multiple range and multiple F test. Biometrics, 11:1-42.

El-Boukhari, M.E ; Barakate, M.; Bouhia, Y. and Lyamlouli, K. (2020). Trends in seaweed extract based biostimulants: manufacturing process and beneficial effect on soil, plant systems. Plants, 9(359):1-23.

El Laban, H.M.; Fetouh, M.I.; Khater, R.M.R. and El-Gioushy, S.H. (2017). Response of Dutch fennel to algae extract partial replacement of mineral NPK under Sinai conditions, J. Plant Production, Mansoura Univ., 8(6):693698.

El-Khateeb, M.A.; El-Attar, Asmaa B.; and Nour, R.M. (2017). Application of plant biostimulants to improve the biological responses and essential oil production of marjoram (Majorana hortensis, Moench) plants. Middle East J. Agric. Res., 6:928941.
Farrell, K.T. (1990). Spices: Condiments and Seasonings, $2^{\text {nd }}$ ed. Springer, USA, $414 \mathrm{p}$.

Frankenberger, W.T. and Arshad, M. (1995). Phytohormones in Soils: Microbial Production and Function. Marcel and Deckker, New York, 503 p.

Ghatas, Y.A.A. (2020). Impacts of using some fertilization treatments in presence of salicylic acid foliar spray on growth and productivity of Coriandrum sativum L. pant, J. of Plant Production, Mansoura Univ., 11(2):119-125.

Graves, A.; Matthews, R. and Waldie, K. (2004). Low external input technologies for livehood improvement in subsistence agriculture. Adv. Agron., 82:473-555.

Guenther, E. (1961). The Essential Oils, vol. 1, 337 ed. D. Van Nostrand Co., Inc., New York., p. 3-13.

Horneck, D.A. and Hanson, D. (1998). Determination of Potassium and Sodium by Flame Emission Spectrophotometry. In Kolra, Y.P. (ed.), Hand Book of Reference Methods for Plant Analysis, Taylor and Francis Group, LLC. p. 153155.

Horneck, D.A. and Miller, R.O. (1998). Determination of Total Nitrogen in Plant Tissue. In Kolra, Y.P. (ed.), Hand Book of Reference Methods for Plant Analysis, Taylor and Francis Group, LLC. 73 p.

Horvath, E.; Szalai, G. and Janda, T. (2007). Induction of abiotic stress tolerance by salicylic acid signaling. Journal of Plant Growth Regulation, 26(3):290- 300.

Hucker, T. and Catroux, G. (1980). Phosphorus in sewage ridge and animal's wastes slurries. Proceeding of the EEC Seminar, Haren (Gr): Gromingen, 12-13 June, Netherlands.

Ibrahim, F.R. and Helaly, A.A.E. (2017). Growth and productivity response to nitrogen, potassium and humic acid of fenugreek (Trigonella foenum-graecum 


\section{Y.F.Y. Mohamed}

L.) plant. Middle East J. Agric. Res., 6(4):1526-1535.

Inskeep, W.P. and Bloom, P.R. (1985). Extinction coefficients of chlorophyll a \& $\mathrm{b}$ in NN-dimethylformade and $80 \%$ acetone. Plant Physiol., 77:483-485.

Jackson, M.L. (1973). Soil Chemical Analysis. Prentice-Hall of Indian Private, New Delhi, India, 478 p.

Kang, Y.Y. and Guo, S.R. (2011). Role of Brassinosteroids on Horticultural Crops. In: Hayat, S. and Ahmad, A. (eds.), Brassinosteroids: A Class of Plant Hormone, Springer, Dordrecht. pp. 269288.

Karalija, E. and Parić, A. (2017). Effects of salicylic acid foliar application on growth and antioxidant potential of basil (Ocimum basilicum L.). Biologica Nyssana, 8(2):145-150.

Koppula, S. and Kumar, H. (2013). Foeniculum vulgare Mill (Umbelliferae) attenuates stress and improves memory in wister rats. Tropical Journal of Pharmaceutical Research, 12(4):553-558.

Mady, M.A.A. (2020). Improvement of The Productivity and Quality of Medicinal and Aromatic Plants for Export. M.Sc. Thesis, Fac. Agric., Benha Univ., 134 p.

Mahdy, H.A.A.; Mubarak, D.M.; El-Azab, M.E.; Mohammed, K.A.S. and Abd ElRheem, K.M. (2019). Effect of foliar spraying with amino acid and cytokinin on growth, yield quality and quantity of nutritional status of roselle plants. Bioscience Research, 16(1):102-109.

Mansori, M.; Farouk, I.A.; Hsissou, D. and El Kaoua, M. (2019). Seaweed extract treatment enhances vegetative growth and antioxidant parameters in water stressed Salvia officinalis L. J. Mater. Environ. Sci., 10(8):756-766.

Maryam, S.; Mohammad, R.H. and Mohammad, T.D. (2014). Effects of amino acids and nitrogen fixing bacteria on quantitative yield and essential oil content of basil (Ocimum basilicum). Agric. Sci. Dev., 3(8):265-268.

Metwally, A.; Finkemeier, I.; Georgi, M. and Dietz, K.J. (2003). Salicylic acid alleviates the cadmium toxicity in barley seedlings. Plant Physiology, 132(1):272281.

Moghith, W.M.A. (2019). Studies on Growth and Productivity of Chia Plant (Salvia hispanica L.) Under Egyptian Conditions, Ph.D. Thesis, Fac. Agric., Benha Univ, Egypt, 198 pp.

Mohamed, S.M.; Abou El-Ghait, E.M.; Ghatas, Y.A.; El Shayieb, N.M. and Shahin, A.A.S. (2015). Effect of some fertilizers on improving growth and oil productivity of basil (Ocimum basilicum, L.) cv. Genovese plant. Egypt. J of Appl. Sci, 30(6):384-399.

Mohamed, Y.F.Y.; Zewail, R.M.Y. and Ghatas, Y.A.A. (2016). The role of boron and some growth substances on growth, oil productivity and chemical characterization of volatile oils in basil (Ocimum basilicum L.) cv. Genovese. Journal of Horticultural Science \& Ornamental Plants, 8(2):108-118.

Müssig, C. (2005). Brassinosteroid-promoted growth. Plant Biol., 7(2):110-117.

Pereira,M.M.A.; Morais, L.C.; Marques, E.A.; Martins, A.D.; Cavalcanti, V.P.; Rodrigues, F.A.; Gonçalves, W.M.; Blank, A.F.; Pasqual, M. and Dória1, J. (2019). Humic substances and efficient microorganisms: elicitation of medicinal plants-a review. Journal of Agricultural Science, 11(7):268-280.

Prins, C.; Vieira, J.C. and Freitas, S.P. (2010). Growth regulators and essential oil production. Braz. J. Plant Physiol., 22(2):91-102.

Rai, V.K. (2002). Role of amino acids in plant responses to stresses. Biologia Plantarum, 45(4):481-487.

Rather, M.A.; Dar, B.A. and Sofi, S.N. (2012). Foeniculum vulgare, a 
comprehensive review of its traditional use, phytochemistry, pharmacology, and safety. Arabian Journal of Chemistry, 2: $1-10$.

Shalaby, A.S; Hendawy, S.F. and Khalil, M.Y. (2011). Evaluation of some types of fennel (Foeniculum vulgare Mill.) newly introduced and adapted in Egypt. Journal of Essential Oil Research, 23(4):35-42.

Smith, S.E.; Jakobsen, I.; Gronlund, M. and Smith, F.A. (2011). Roles of arbuscular mycorrhizas in plant phosphorus nutrition: interactions between pathways of phosphorus uptake in arbuscular mycorrhizal roots have important implications for understanding and manipulating plant phosphorus acquisition. Plant physiology, 156(3):1050-1057.

Snedecor, G.W. and Cochran, W.G. (1989). Statistical Methods, $8^{\text {th }}$ ed. Iowa State University Press, Ames, 503 p.
Taiz, L. and Zeiger, E. (2002). Plant Physiology, $3^{\text {rd }}$ ed. Sinauer Associates Inc., Sunderland, $690 \mathrm{p}$.

Veresoglou, S.D.; Shaw, L.J. and Sen, R. (2011). Glomus intraradices and Gigaspora margarita arbuscular mycorrhizal associations differentially affect nitrogen and potassium nutrition of Plantago lanceolata in a low fertility dune soil. Plant Soil, 340(1-2):481-490.

Wichtl, M. and Bisset, N.G. (1994). Herbal Drugs and Phytopharmaceuticals. Medpharm Scientific Publishers, Stuttgart, Germany, 566 p.

Zhang, X. and Schmidt, R.E. (1997). The impact of growth regulators on the atocopherol status in water-stressed Poa pratensis L. Int. Turfgrass Res. J., 8:1364-1373.

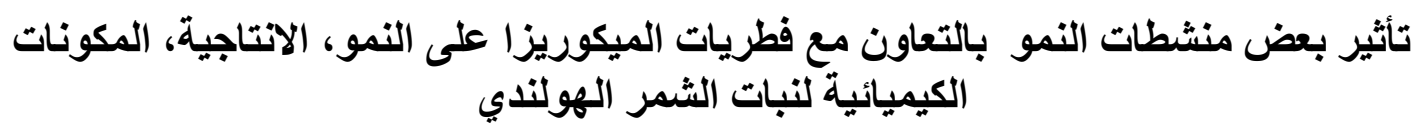

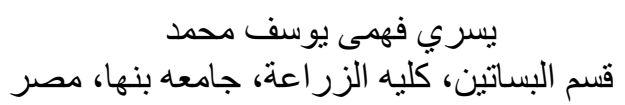

الثمر نبات طبي و عطري مهم يحتل المرتبة الأولى في قائمة الصادرات المصرية من الأعشاب و التوابل. يتميز

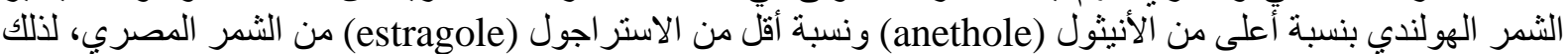

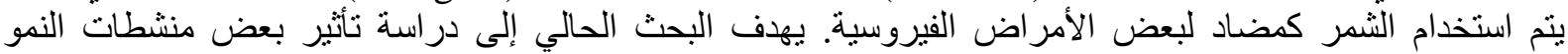

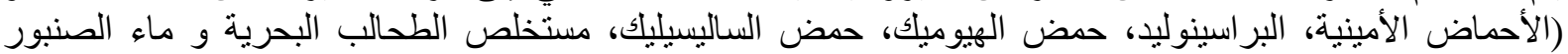

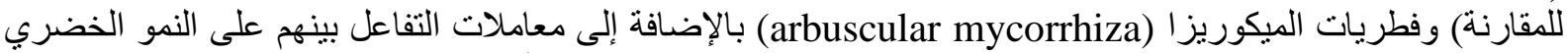

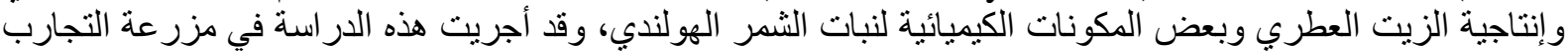

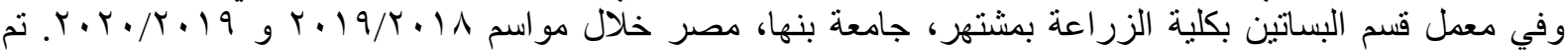

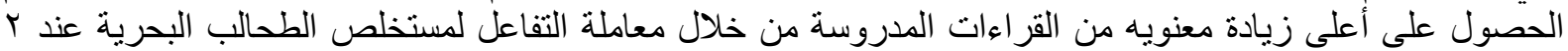

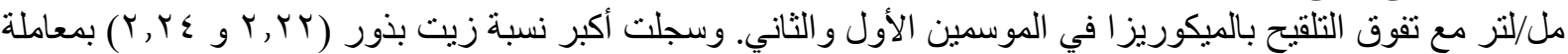

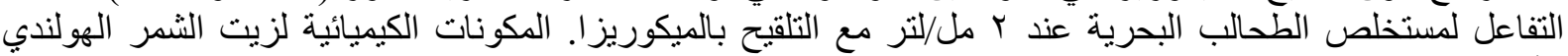

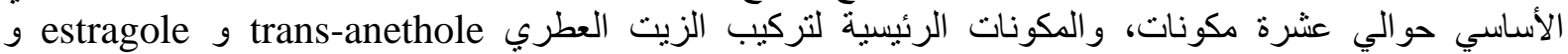

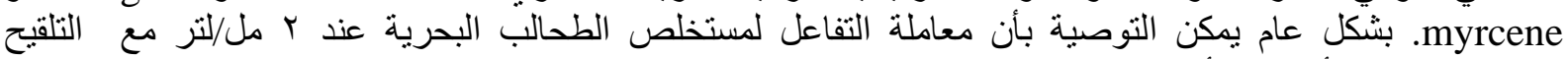
بالميكوريز ا يمكن أن تحقق أكبر نمو، وانتاجية ، ومكونات كيميائية للثمر الهولندي. 